\title{
Implications of Using Technology on Children, Teachers and Parents in Early Education
}

\author{
Liliana Mâță, Otilia Clipa
}

It is increasingly recognized that the emphasis must be on integrating technology as a teaching instrument for all levels of the educational system, but less in kindergarten. In this chapter there are analyzed the main implications of using technology during early education. The first part includes a description of the advantages of using digital resources in early education both for teachers and for children. In the second part, the impact of the use of technology on the cognitive and socio-emotional development of children is highlighted. The third part describes some concrete ways of innovative integration of technology in kindergarten by educators, as well as a series of rules that must be followed by parents for the optimal use of technology in preschool age.

Keywords: Cognitive development, early education, parents, socioemotional development, teachers, technology

\section{Introduction}

Information and communication technology is becoming a key tool for building the knowledge society and, in particular, a mechanism through which early education could provide a way to rethink and redesign education systems and processes, thus leading to quality education for all. The use of new technologies is a social response to the growing demand for education, the need to diversify training offers and institutions, on multiple levels: teachers, mixed learning communities, content circulated, means of evaluation, management procedures, management procedures. Sangrà and González-Samamed (2010) emphasizes that in recent years, several studies and reports have highlighted the potential opportunities and benefits of information and communication technologies to improve the quality of education.

The use of technology registers some highlights at preschool and preschool ages. Although the use of technology is recommended as little as possible at an early age, the attraction of children to the variety of digital 
resources around them cannot be minimized. According to Danovitch (2019), children of the current generation are exposed to increasingly varied technologies, such as computers, tablets, smartphones and other Internetbased devices from birth and using them not long after. The first explosion takes place between the ages of 3 and 4 , followed by a second one, at the age of 8 , and another one, when the children are 12-13 years old and go to high school (Gold, 2016). Every year there is an increase in the time spent with digital technology, the number of devices and the ways in which they are used. Children between the ages of 2 and 4 spend about three hours a day in front of a screen, but this figure will increase to seven hours and three quarters a day when they reach the end of elementary school. In early age period, the use of television as a technological tool predominated. The most important transition in children's lives is the transition from passive watching TV and videos to accessing various games and using applications before school starts.

In the last decade, the evolution of children's use of the Internet has been characterized by two main directions, both of which put parents and teachers in a crucial role in protecting children from the risks of the online environment (Roman, 2014): access the Internet from an early age, the mobile character and the accessibility, as a result of the possibility to use technology from anywhere and anytime. Within only 2 years, between 2011 and 2013, the number of children under 8 who used an application tripled, from $16 \%$ to $50 \%$. Statistics from Romania and around the world show that many preschool children are able to use different Internet access devices and even do so with or without parental supervision. Also, statistics indicate that $98 \%$ of American children between the ages of 0 and 8 live in homes with devices that can access the Internet (Rideout, 2017). The question is no longer whether children use digital technology, but how, why and with what effects (2015). Currently, there is an exponential increase in the need for digitization of the Romanian education system, which will now be forced to go through all the typical digitization processes (Tudor and Popescu, 2020), starting with digitization. This is an argument for the training and mobilization of educators in the preschool education system to prepare children for the correct use of technology. There is a need for a digital transformation, which involves the creation of innovative educational concepts ( $\mathrm{Rad}$ et al., 2020). 
Trends and Prospects of the Education System and Educators' Professional ...

\section{The advantages of digital resources for teachers and children in early education}

The use of the technological instruments leads to qualitative changes in carrying out instructive-educational activities in kindergarten, because it ensures a saving of time for the adequate use of teaching aids and teachinglearning methods. Technological resources offer new possibilities for the creative development of children and teachers, by giving up boring traditional training activities, as well as for the establishment of new means of expression (Greenfield, 2005). The positive effects of the use of new technologies are multiple: individualization of learning activities, logical ordering of curricular contents, as well as streamlining the communication process during play and learning activities. Table 1 presents the advantages of using technology in carrying out activities in early education for both teachers and children, adapted after Sangrà and González-Samamed (2010).

The new technologies are only a supplement, which has no negative effects if used in moderation by teachers and parents. A major benefit that technological resources offer is the support and strengthening of relationships and communication between all representatives involved in early education, such as educators, parents and community members.

\section{The impact of using technology on the cognitive and socio- emotional development of preschool children}

The introduction of informational resources in early education has a great impact on cognitive and socio-emotional development in preschoolers. The early education period is a very important stage of development, as children «actively explore and learn about the world around them, as their cognitive and social skills develop rapidly» (Danovitch, 2019).

\subsection{The consequences of using technology on cognitive development}

From the perspective of cognitive development, children can use technology to watch video or TV presentations, to achieve group projects or to make audio or video recordings of objects they create. Digital technology is also a very useful resource for documentation. The increasing use of technology by children in the last decade has led to the start of studies to understand how time spent in digitally mediated activities can affect in positive or negative ways (Bell et al., 2015; Kardefelt-Winther, 2017). 
Tab.1. The advantages of using technology in early education for teachers and children

\begin{tabular}{|c|c|}
\hline Advantages for teachers & Advantages for children \\
\hline $\begin{array}{l}\text { - increasing educational time focused on } \\
\text { the interaction of teaching processes, } \\
\text { learning and evaluation; } \\
\text { - extension of the teacher's time space as } \\
\text { time for preparation for educational } \\
\text { activities and for self-development and } \\
\text { career development; } \\
\text { - valorization of didactic resources as an } \\
\text { expression of the diversity, quality, } \\
\text { accessibility of the educational processes } \\
\text { oriented towards the children's } \\
\text { performances; } \\
\text { - creating a varied instrumental support } \\
\text { that stimulates the involvement and } \\
\text { participation of children in instructive- } \\
\text { educational activities; } \\
\text { - encouraging individual study and specific } \\
\text { discovery learning methodologies; } \\
\text { - stimulating the creativity of teachers in } \\
\text { the educational process by promoting } \\
\text { teamwork; } \\
\text { - building teaching experiences that } \\
\text { integrate and stimulate emotional learning; } \\
\text { - strengthening the mechanisms of } \\
\text { personal feedback through the self- } \\
\text { evaluation of the educational activity; } \\
\text { - diversification of evaluation strategies } \\
\text { and procedures in order to increase the } \\
\text { - stimulating the connection between the } \\
\text { experiential fields by using the integrated } \\
\text { - ond regional and local development; } \\
\text { enjectivity of evaluation; } \\
\text { - }\end{array}$ & $\begin{array}{l}\text { - increasing the share of time for play } \\
\text { and learning activities in kindergarten; } \\
\text { - giving more time for personal } \\
\text { development and constructive leisure } \\
\text { activities; } \\
\text { - the use of new technologies } \\
\text { necessary resources in play and } \\
\text { learning activities in order to ensure } \\
\text { diversity, quality, accessibility of the } \\
\text { child-centered educational process; } \\
\text { - providing intrinsic motivational } \\
\text { support to children in approaching } \\
\text { educational communication by giving } \\
\text { more dynamism to the reception of the } \\
\text { message; } \\
\text { - providing group support for training } \\
\text { differentiation; } \\
\text { - developing creativity at the individual } \\
\text { level as well as at the group level by } \\
\text { activating teamwork skills; } \\
\text { - emotional involvement in different } \\
\text { learning situations by raising awareness } \\
\text { of children's reactivity and empathy; } \\
\text { - developing personal feedback } \\
\text { mechanisms through self-assessment } \\
\text { of activity, awareness of potential and } \\
\text { increased self-confidence; } \\
\text { - increase the confidence } \\
\text { preschoolers in the process of } \\
\text { objective evaluation through the use of } \\
\text { self-evaluation and group evaluation; } \\
\text { - access to global communication with } \\
\text { the help of technological resources; } \\
\text { - receiving knowledge and developing } \\
\text { the skills of preschoolers in an } \\
\text { integrated manner; }\end{array}$ \\
\hline
\end{tabular}


Trends and Prospects of the Education System and Educators' Professional ...

approach;

- improving play and learning activities for

students with special educational needs

- adapting play and learning activities for students with special educational needs

The experimental research has shown the short-term improvement of cognitive skills as a result of preschool children's participation in games based on cognitive skills. The main benefits were highlighted in terms of developing visual and attentional processing skills (Green and Bavelier, 2003, 2007), iconic and spatial representative skills (Greenfield et al., 1994; Subrahmanyam and Greenfield, 1994), as well as executive function skills (Rueda et al., 2005) and visual spatial working memory (Thorell et al., 2009). Brain development patterns and active knowledge in digital children may differ from those of children of past generations, as a result of spending more time in technological games (Bergen, 2015). Some studies based on the content of the game (Subrahmanyam and Renukarya, 2015) have reported negative results in terms of learning and educational outcomes. In the future, children's games will include devices with an ever-increasing technological component. Therefore, Bergen (2015) recommends an increased attention to the design of technological devices based on game models that encourage embodied experiences, in order to promote active knowledge.

Regarding the child's exposure to television, some studies did not find correlations with cognitive development, while others showed a negative impact, depending on the child's age and the educational nature of the programming (Zimmerman and Christakis, 2005). The cognitive impact of television use on children under 3 years of age is related to exposure time, program content and social context. For children under 2 years of age, the research results found negative aspects of cognitive development, especially in language development and executive function (Barr et al., 2010) due to exposure to programming produced for adults. The results of the study by Chonchaiya and Pruksananonda (2008) showed that children, who started watching TV before the age of 12 months and watched more than 2 hours on TV every day, are six times more likely to register the delay in language development. Following a longitudinal study, Alloway et al. (2014) observed that educational books had a greater impact on vocabulary development than television. Danovitch (2019) considers that it is essential to understand the influence that early and prolonged exposure to Internet-based devices can have on children's cognitive development.

The experience of searching for information on the internet can be to the advantage of young children. However, the use of the Internet can become an impediment to learning and exploration, if children get used to 
finding information quickly and easily, which causes them to give up faster when they encounter more complex obstacles or problems (Danovitch, 2019). Research shows that Internet access amplifies children's assessment of their knowledge, which can diminish their curiosity and motivation to acquire new information (Ward, 2013). Thus, if the use of the Internet artificially creates the feeling of knowledge or understanding of children about a topic, then they may be less motivated to seek additional information on this topic.

\subsection{The effects of using technology on socio-emotional development}

The negative effects on affective and social development of children generated by the increased use of digital technology range from mental health problems, such as depression or addiction (Kim et al., 2010), to public health problems such as obesity (Sisson et al., 2010). The use of technological devices can be a factor that can inhibit the emotional development of children, because their emotional development is less stimulated (Suhana, 2017). Therefore, children no longer have stable emotions because affective development is acquired when children interact with their environment. The use of technological resources by children for a long time will determine addiction and negative effects on their emotional development, as well as a poorer understanding of social reality, due to their lack of interaction. The involvement of young children for a long time in technology-augmented play can lead to fewer interactions with parents, other children and even with physical objects in the environment (Bergen, 2015). Also, there is evidence that violent computer games can influence antisocial and aggressive behavior (Gentile et al., 2004). Another negative effect of the use of technological resources is dependence. Children who are addicted to technological tools are more aggressive and less able to control their emotions when they feel disturbed or when their device is faulty (Suhana, 2017). Digital children interact more with the phone than with others, which can lead to missing important social experiences (Turkle, 2011). As a result of addiction, children tend to be closer to their device so that they feel that they cannot be separated from the device.

Although several negative effects are highlighted in terms of socioemotional development, there are studies that show that digital technology brings great benefits to children due to its interactive features (Boyd, 2014) and daily use at home for social interaction and relaxation with family (Enevold, 2012). In this context, Boyd (2014) claim that children still interact with each other as much as before and that interrelationships are of a similar quality. Only places of social interaction have changed, becoming digital. 
Research based on investigating the effects of technology use on socio-emotional development at an early age leads to recommendations on the roles that adults should play in supporting children's interactions. It is important that with the use of technology, young children have many experiences in the the «real world» (Bergen, 2015) that involve playing with parents and children of different ages, playing outdoors and indoors, as well as establishing physical interactions with concrete materials. After Bergen et al. (2015), the young children must continue to have «multiple experiences with the natural environment and the human social world, as well as the technology world if human versatility and resilience are to continue to exist». Children will not become dependent on technological devices if parents have a priority role for children's development (Suhana, 2017). It is important for parents to take an active role in supervising and controlling their children in the use of technology, so that their socio-emotional development is not delayed due to its excessive use.

\section{New challenges for teachers and parents in using technological resources}

At the age of early education, the integration of new technologies is a real challenge for both educators and children, parents and the entire educational community. Gold (2016) highlights the need to develop as early as possible a systematic approach to digital technology, with clear rules and open communication. It is essential that educators and parents understand the use of digital technology in terms of the stages of personal development of the child. From 0 to 2 years, parents learn how to manage the child's digital universe before preschool. The age period from 3 to 5 years is when digi-kids and techno-kids are already learning from kindergarten everything they need to know about the digital universe.

\subsection{The role of teachers in the innovative use of technology in kindergarten}

The role of the use of information technologies is to provide a multitude of tools, procedures and methods to facilitate the transition from a learning environment focused on the teacher and the printed teaching material, to an interactive environment, focused on the child and the process of assimilating knowledge taught, in a pleasant and collaborative environment. The teaching process is no longer considered to be the result of the teacher's efforts, but of the preschooler's interaction with the factors that direct the learning act, such as technological tools, as adequate information resources. 
Information and communication technologies can be successfully integrated into early education activities from several perspectives. Regarding the curricular contents, the teachers can create various supports and didactic means attractive for children with the help of various technologies. Teachers can also use a variety of teaching materials that exist only on electronic media, as well as a variety of complementary content. Referring to the management procedures at the level of the school organization, the technological resources can be used for the management of the children, as well as for the online registration or for the selection of the children. At the same time, new technologies can be used by teachers to carry out extracurricular activities in various ways: using online resources, organizing collaborative activities at a distance, participating in online communities of practice or in virtual groups. The educators will make their own decisions about the nature and extent of the use of information and communication technologies in children's learning.

The most used technological tools with which teachers can design and conduct attractive activities in early education are the computer, video projector, DVD player, interactive whiteboard, printer, tablet, digital camera, software tools and electronic communication tools. With the help of these technological resources, children play virtual tables, solve a puzzle on a tablet, communicate on Skype with groups of children from other parts of the world. Teachers can use the computer in educational activities in kindergarten in various forms, such as: viewing sequences of stories, making practical applications, preparing children to transmit information, simulating teaching games, evaluating learning outcomes. The implementation of innovative digital systems, such as the interactive whiteboard in the teaching process in early education is no longer seen as a modern teaching tool, but has become a great necessity (Manny-Ikan, 2011; Clipa \& Juravle, 2019). The video projector offers teachers the opportunity to create attractive PowerPoint presentations on various topics in early education. Teachers can also present films and images to teach children about the world and places they have never seen or imagined. In this context, it is important for educators to understand the need to play in the real world and the child's desire to explore. The printer remains an indispensable digital tool for carrying out early childhood activities, as children want to be able to print the products of the activity, while teachers need to be able to print worksheets, lesson plans and other specific curriculum documents. The possibilities of using the digital camera in early education are multiple: developing digital portfolios, getting photos with children to write about themselves, observing the weather, illustrating simple experiments such as growing a plant, creating digital stories. With the help of tablets, teachers can 
develop personalized activity projects that are adapted to children's learning style.

\subsection{Rules for the optimal use of technology by parents at preschool age}

The pitfalls of using technology come when parents place a TV or computer in their child's bedroom or when they leave the TV on all the time. Currently, in the US, more than a third of children between the ages of two and five have a TV in the bedroom. The TV in the bedroom or the one that works permanently generates sedentary behavior and extensive and inadequate media exposure.

To protect the child from the negative effects of technology, Gold (2016) proposes several rules:

- avoid placing the TV or digital devices in the bedroom, as they can cause obesity, metabolic abnormalities and sleep disorders;

- turning of the TV when no one is watching, as it distracts from human interaction and leads to inappropriate exposure;

- interruption of electronic devices at least half an hour before bedtime, as the use of technology at night and the bluish light emitted by the screen can disturb sleep and cause physical, behavioral and emotional problems;

- offering the child more opportunities to play actively from a physical point of view, in order to eliminate sedentary lifestyle;

- involving the child in imaginary games played in the real world, to stimulate social and emotional development.

The possibilities of using information and communication technologies are varied by both educators and parents. Bolstad (2004) provides several examples of the roles of technology in early education (Table 2).

Tab. 2. Ways of using technology by children and practitioners in early education

\begin{tabular}{|l|l|}
\hline \multicolumn{1}{|c|}{ Ways of using technology } & \multicolumn{1}{|c|}{ Examples } \\
\hline $\begin{array}{l}\text { - the use of technology by } \\
\text { children in play or learning } \\
\text { activities (alone, with colleagues } \\
\text { or adults) }\end{array}$ & $\begin{array}{l}\text { - playing games, listening to stories or drawing } \\
\text { - making role-playing games }\end{array}$ \\
\hline
\end{tabular}




\begin{tabular}{|c|c|}
\hline $\begin{array}{l}\text { - the capitalization of new } \\
\text { technologies by children and } \\
\text { practitioners for learning }\end{array}$ & $\begin{array}{l}\text { - the discovery of information with the help of } \\
\text { the internet, as a result of the children's interest } \\
\text { in a certain subject }\end{array}$ \\
\hline $\begin{array}{l}\text { - the use of ICT by children and } \\
\text { practitioners for documentation } \\
\text { and reflection activities on } \\
\text { children's learning or to share } \\
\text { learning with parents }\end{array}$ & $\begin{array}{l}\text { - making digital photos, videos or audio } \\
\text { recordings of activities and viewing them by } \\
\text { parents; } \\
\text { - developing portfolios in order to assess } \\
\text { progress in children's learning and development }\end{array}$ \\
\hline $\begin{array}{l}\text { - the use of technological } \\
\text { resources by practitioners for } \\
\text { information } \\
\text { administration and management }\end{array}$ & $\begin{array}{l}\text { - designing individual learning plans for } \\
\text { children or using computerized templates to } \\
\text { plan children's learning; } \\
\text { - creating databases to keep track of important } \\
\text { information about children and their families }\end{array}$ \\
\hline $\begin{array}{l}\text { - use of technology by children } \\
\text { and practitioners to communicate } \\
\text { or exchange information with } \\
\text { other practitioners, parents or } \\
\text { researchers }\end{array}$ & $\begin{array}{l}\text { - communicating with other practitioners, } \\
\text { parents, or researchers through video } \\
\text { conferencing, online discussion communities, } \\
\text { or e-mail; } \\
\text { - keeping in touch with parents who cannot } \\
\text { come to the early childhood education center } \\
\text { by telephone, e-mail or fax }\end{array}$ \\
\hline
\end{tabular}

An increasing number of parents and teachers have noticed that preschoolers will be better prepared for life and material well-being in a changing world as a result of the use of technological tools. Technology must be used in a balanced way in early age, associated, as Gold (2016) mentions, with «instilling a sense of collaboration, creativity and digital citizenship». In early education, digital citizenship aims to build an ethical and empathic foundation for the experiences in the virtual world that children will have. The responsible ethical use of technology (Mâță et al., 2020) becomes a requirement of today's society, so it is necessary to form this skill from an early age.

\section{Conclusions}

Following the major changes in the knowledge society, there is an increasing need for a child-centered education system, in which to focus on the level of development of its capabilities, using appropriate technological tools. It is obvious that more and more classrooms in kindergarten will become digital, with a steady increase in the use of tablets, computers and other mobile devices. On the one hand, teachers are determined to propose 
innovative ways in which technology can be flexibly integrated as a teaching resource in the activities from early education. On the other hand, parents are forced to learn the rules of using technological resources in order to achieve an optimal and balanced integration of them in informal activities. The analysis of the impact that the use of technological resources has on the cognitive and socio-emotional development of young children highlights the importance of involving all educators and parents in the correct management of devices and their tactful integration in the positive education of the next generation.

\section{Acknowledgement}

"This work was supported by a grant of the Ministry of Education and Research, project number SMIS POCU/446/6/22/128215/."

\section{References}

Alloway, T. P., Williams, S., Jones, B., \& Cochrane, F. (2014). Exploring the impact of television watching on vocabulary skills in toddlers. Early Childhood Education Journal, 42(5), 343-349.

Barr, R., Lauricella, A., Zack, E., \& Calvert, S. L. (2010). Infant and early childhood exposure to adult-directed and child-directed TV programming. MerrillPalmer Q., 56(1), 21-48.

Bell, V., Bishop, D. V. M., \& Przybylski, A. K. (2015). The debate over digital technology and young people. British Medical Journal, 351, Article h3064. doi:10.1136/bmj.h3064.

Bergen, D. (2015). Potential Effects of a Technology Pervasive World on Young Children's Brain Development. Pediat Therapeut, 5(3), 256. doi:10.4172/21610665.1000256.

Bergen, D., Davis, D., Abbitt, J. (2015). Technology play and brain development: Infancy to adolescent and future implications. New York: Taylor \& Francis.

Bolstad, R. (2004). The role and potential of ICT in early childhood education. A review of New Zealand and international literature. Wellington: Ministry of Education, Early Childhood Education, New Zealand Council for Educational Research.

Boyd, D. (2014). It's complicated: The social lives of networked teens. New Haven, CT: Yale University Press.

Clipa, O. \& Juravle, V. (2019). The roles of the online environment in schoolfamily communication, Innovation, Technologies and Research in Education, University of Latvia Press, 289 - 300. )

https://doi.org/10.22364/atee.2019.itre 
Chonchaiya, W., \& Pruksananonda, C. (2008). Television viewing associates with delayed language development. Acta Paediatr, 97(7), 977-82. doi: 10.1111/j.1651-2227.2008.00831.x.

Danovitch, J. H. (2019). Growing up with Google: How children's understanding and use of internet-based devices relates to cognitive development. Hum Behav \& Emerg Tech, 1, 81-90.

Enevold, J. (2012). Domesticating play, designing everyday life: the practice and performance of family gender, and gaming. In K. Raine, M. Frans, S. Jaakko (Eds.), Proceedings of 2012 DiGRA Nordic (pp. 13). Tampere: University of Tampere.

Gentile, D. A., Lynch, P. J., Linder, J. R., \& Walsh, D. A. (2004). The effects of violent video game habits on adolescent hostility, aggressive behaviors, and school performance. $J$ Adolesc., 27(1), 5-22.

George, M. and Odgers, C. (2015). Seven fears and the Science of How Mobile Technologies May Be Influencing Adolescents in the Digital Age. Perspectives on Psychological Science, 10(6), 832-851.

Gold, J. (2016). Părinte în era digitală. Învațăți copilul cum să folosească adecvat rețelele sociale şi aparatele digitale Parent in the digital age. Teach your child how to use social media and digital devices properly]. Bucharest: Trei Publisher.

Green, C. S., \& Bavelier, D. (2003). Action video game modifies visual selective attention. Nature, 423(6939), 534-537.

Green, C. S., \& Bavelier, D. (2007). Action-videogame experience alters the spatial resolution of vision. Psychological Science, 18(1), 88-94.

Greenfield, D. N. (2005). Virtual Addiction: Help for Netheabs, Cyber and Those Who Love Theam. New York.

Greenfield, P. M., Brannon, C., \& Lohr, D. (1994). Two-dimensional representation of movement through threedimensional space: the role of video game expertise. J Appl Dev Psychol., 15(1), 87-103.

Kardefelt-Winther, D. (2017). How does the time children spend using digital technology impact their mental well-being, social relationships and physical activity? An evidencefocused literature review. Florence. UNICEF.

Kim, J., Lau, C., Cheuk, K. et al. (2010). Brief report: Predictors of heavy Internet use and associations with health-promoting and health risk behaviors among Hong Kong university students. Journal of Adolescents, 33, 215-220.

Manny-Ikan, E. Dagan, O., Tikochinski, Zorman, R. (2011). Using the Interactive White Board in Teaching and Learning - An Evaluation of the SMART CLASSROOM, Pilot Project. Interdisciplinary Journal of E-Learning and Learning Objects, Vol. 7, 249-273.

Mâță, L., Clipa, O., Tzafilkou, K. (2020). The Development and Validation of a Scale to Measure University Teachers' Attitude towards Ethical Use of 
Information Technology for a Sustainable Education. Sustainability, 12(15), 6268, DOI: $10.3390 /$ su12156268.

Rad, D., Demeter, E., Ignat, S., Rad, G. (2020). Digitization of Everything, the world of $0 \mathrm{~s}$ and $1 \mathrm{~s}$, emerging trends in psychological assessment. Agora Psycho-Pragmatica, 14(1).

Roman, G. (Ed.) (2014). Ghidul utilizării în siguranţă a Internetului [Internet Safe Use Guide]. Bucharest: Ministry of Education.

Rueda, M. R., Rothbart, M. K., McCandliss, B. D., Saccomanno, L., Posner, M. I. (2005). Training, maturation, and genetic influences on the development of executive attention. Proc Natl Acad Sci USA, 102(41), 14931-14936.

Rideout, V. (2017). The common sense census: Media use by kids age zero to eight [PDF]. San Francisco, CA: Common Sense Media.

Sangrà A., \& González-Sanmamed M. (2010). The role of information and communication technologies in improving teaching and learning processes in primary and secondary schools. Research in Learning Technology, 18(3), 207-220.

Sisson, S. B., Broyles, S. T., Baker, B. L. (2010). Screen time, physical activity, and overweight in U.S. youth: National Survey of Children's Health 2003. Journal of Adolescent Health, 47, 309-311. doi:10.1016/j.jadohealth.2010.02.016

Subrahmanyam, K, \& Greenfield, P. M. (1994). Effect of video game practice on spatial skills in girls and boys. J Appl Dev Psychol., 15(1), 13-32.

Subrahmanyam, K., \& Renukarya, B. (2015). Digital games and learning: identifying pathways of influence. Educ Psychol., 50(4), 335-348.

Suhana, M. (2017). Influence of Gadget Usage on Children's Social-Emotional Development. Advances in Social Science, Education and Humanities Research (ASSEHR), Volume 169, 224-227.

Thorell, L. B., Lindqvist, S., Bergman, Nutley S., Bohlin, G., Klingberg, T. (2009). Training and transfer effects of executive functions in preschool children. Dev Sci., 12(1), 106-113.

Tudor, S. L., \& Popescu, A. M. (2020). E-Inclusion Versus Digital Divide - A Challenge for Romanian Educational System within the Context of Coronavirus Pandemic Growth. Journal Plus Education, Vol. XXV, No.1, 374381.

Turkle, S. (2011). Alone Together: Why we expect more from technology and less from each other. New York: Basic Books.

Ward, A. F. (2013b). Supernormal: How the Internet is changing our memories and our minds. Psychological Inquiry, 24, 341-348. https://doi.org/10.1080/1047840X.2013.850148.

Zimmerman, F. J., \& Christakis, D. A. (2005). Children's television viewing and cognitive outcomes: a longitudinal analysis of national data. Arch Pediatr Adolesc Med., 159(7), 619-625. 